Olga Partykal, Monika Pajewska , Magdalena Krysińska-Pisarek ${ }^{2}$, Katarzyna Domosławska-Żylińska ${ }^{2}$, Joanna Bulira-Pawetczyk ${ }^{2}$, Aleksandra Czerw ${ }^{1}$

\title{
SIN TAX AS A PUBLIC HEALTH TOOL - STRENGTHS AND WEAKNESSES OF THIS ECONOMIC SOLUTION
}

\section{SIN TAX JAKO NARZĘDZIE ZDROWIA PUBLICZNEGO - MOCNE I SŁABE STRONY ROZWIĄZANIA EKONOMICZNEGO}

\author{
${ }^{1}$ Department of Economic and System Analysis, National Institute of Public Health-National \\ Institute of Hygiene \\ ${ }^{2}$ Department of Public Health Education and Communication, Narodowy Instytut Zdrowia Publicznego - \\ Państwowy Zakład Higieny \\ ${ }^{1}$ Zakład Analiz Ekonomicznych i Systemowych, \\ ${ }^{2}$ Zakład Kształcenia i Komunikacji w Zdrowiu Publicznym
}

\section{ABSTRACT}

OBJECTIVE. The aim of the paper is to present in a synthetic way the sin tax tool, the mechanisms of its functioning, challenges related to the tool and examples of the application of this tax in selected countries.

MATERIAL AND METHOD. In accordance with Agency for Health Technology Assessment and Tariff System guidelines, a review of literature in the PubMed and Cochrane scientific databases was conducted on the basis of search searches. They searched grey literature and institutional documents of health organizations and legal acts of selected countries that introduced sin tax in the period since 2005.

RESULTS. Sin tax is a public health tax that aims to reduce the negative health attitudes of the population through the use of a price regulation mechanism. In order to prepare an effective economic tool, it is important to model it properly. Today, 35 countries around the world have introduced an additional tax on tobacco products, which is wholly or partly used for health care. In 9 countries, targeted taxes have been introduced on a component whose excessive consumption adversely affects health (sugar, salt, fats).

CONCLUSIONS. Sin tax is a tool that, if properly implemented, can contribute to changing consumer behaviour and thus have a positive impact on the health of the population. It should be remembered that decisions taken at the central level, especially those concerning the introduction of new taxes, should be supported by reliable analyses. Although sin tax is undoubtedly an effective and increasingly widely used tool, it is not free from defects. One of its major drawbacks is its regressive character and potential negative social perception.

Keywords: sin tax, public health, health policy

\section{STRESZCZENIE}

CEL PRACY. Celem pracy jest przedstawienie w sposób syntetyczny narzędzia sin tax, przybliżenie mechanizmów jego funkcjonowania, wyzwań związanych z narzędziem oraz przykładów zastosowania tego podatku w wybranych krajach.

MATERIAL I METODA. Zgodnie z wytycznymi AOTMiT na podstawie kwerend wyszukiwania przeprowadzono przegląd piśmiennictwa w bazach naukowych PubMed i Cochrane. Przeszukano literaturę szarą oraz dokumenty instytucjonalne organizacji zajmujących się zdrowiem oraz aktów prawnych wybranych państw, które wprowadziły sin tax w okresie od 2005 roku.

WYNIKI. Sin tax jest to podatek zdrowia publicznego, którego celem jest ograniczenie negatywnych postaw zdrowotnych społeczeństwa poprzez wykorzystanie mechanizmu regulacji ceny. W celu przygotowania skutecznego narzędzia ekonomicznego ważne jest jego odpowiednie modelowanie. Obecnie 35 państw na świecie wprowadziło dodatkowy podatek od wyrobów tytoniowych, który w całości lub częściowo przeznaczany jest na ochronę zdrowia. W 9 krajach wprowadzono podatki celowane na składnik, którego nadmierne spożycie wpływa niekorzystnie na zdrowie (cukier, sól, tłuszcze). 
WNIOSKI. Sin tax jest narzędziem, które odpowiednio zaimplementowane może przyczynić się do zmiany zachowań konsumentów, tym samym pozytywnie wpływając na stan zdrowia populacji. Należy pamiętać, by decyzje podejmowane na szczeblu centralnym, zwłaszcza dotyczące wprowadzenia nowych podatków, były poparte rzetelnymi analizami. Choć sin tax jest niewątpliwie narzędziem skutecznym i coraz szerzej stosowanym, nie jest pozbawiony wad. Jednym $z$ większych jego mankamentów jest regresywny charakter oraz potencjalny negatywny odbiór społeczny.

Slowa kluczowe: sin tax, zdrowie publiczne, polityka zdrowotna

\section{INTRODUCTION}

Taxes traditionally fulfil three functions: they increase revenues for public (fiscal) benefits, transfer financial resources to persons requiring support in the name of the principle of social solidarity (regulatory) and may be used to modify behaviour (stimulative). Experts recognise that the tax system plays a role in supporting other policy objectives, hence the considerable interest of policy makers in the use of economic tools for public health (1). This very idea of taxation is the basis for sin tax. The sin in question is the consumption of products with proven harmful effects on health. Such a tax has a double role. First of all, it aims to limit the availability and consumption of harmful products, and secondly, it increases the financial resources allocated to health care.

Sin tax is an economic tool that has been operating in its present form since the 1980s. On the basis of research and observations it appears that such a tax is a good tool for regulating the consumption of unhealthy products, but it is not devoid of defects. The main argument against this tax is its regressive character, which makes it much more burdensome for people in a weaker socio-economic situation (2).

More and more countries around the world are reaching for new solutions to the epidemic of civilization diseases, which can be prevented by changing people's behaviors. Sin tax is often mentioned as a tool in the prevention of such diseases, especially in the case of obesity and diabetes (3). The World Health Organization recommends the introduction of economic solutions, including taxes, at the national level in order to comprehensively prevent obesity (3).

\section{WORK OBJECTIVES}

The aim of this article is to present an outline of the sin tax tool as a tool of health policy. Presentation of $\sin$ tax activities on examples in selected countries, indication of its strengths and weaknesses and possible challenges of implementation.

\section{MATERIAL AND METHODS}

First of all, the scientific literature was reviewed. Based on searches based on the following keywords:

\section{WSTĘP}

Podatki tradycyjnie spełniają trzy funkcje - zwiększają przychody na świadczenia publiczne (fiskalna), przenoszą środki finansowe na osoby wymagające wsparcia w imię zasady solidarności społecznej (regulacyjna) oraz mogą być używane do modyfikowania zachowania (stymulacyjna). Specjaliści uznają, że system podatkowy odgrywa pewną rolę we wspieraniu innych celów polityki, dlatego znaczne zainteresowanie ze strony decydentów wykorzystaniem narzędzi ekonomicznych dla zdrowia publicznego (1). Właśnie ta idea podatków jest podstawą działania sin tax, czyli podatku od grzechu. Grzech, o którym mowa stanowi spożywanie produktów o udowodnionym szkodliwym działaniu na zdrowie. Taki podatek ma podwójną rolę. Przede wszystkim ma za zadanie ograniczać dostępność i konsumpcję szkodliwego produktu, po drugie zwiększa środki finansowe przeznaczane na ochronę zdrowia.

Sin tax jest narzędziem ekonomicznym, które w obecnej formie działa od lat 80 . XX wieku. Na podstawie badań i obserwacji wynika, iż taki podatek jest dobrym narzędziem regulującym spożycie niezdrowych produktów, jednak nie jest pozbawiony wad. Jako główny argument przeciw temu podatkowi wskazywany jest jego regresywny charakter, przez co znacznie bardziej obciąża osoby w słabszej sytuacji socjoekonomicznej (2).

Coraz więcej państw na świecie sięga po kolejne rozwiązania w kwestii epidemii chorób cywilizacyjnych, którym można zapobiegać poprzez zmianę zachowań ludzi. Sin tax jest często wymieniany jako narzędzie w zapobieganiu tego typu chorobom, szczególnie w przypadku otyłości i cukrzycy (3). Światowa Organizacja Zdrowia rekomenduje wprowadzanie rozwiązań ekonomicznych, w tym podatków, na poziomie krajowym w celu kompleksowej profilaktyki otyłości (3).

\section{CEL PRACY}

Celem niniejszego artykułu jest przedstawienie zarysu narzędzia sin tax jako narzędzia polityki zdrowotnej. Zaprezentowanie działania sin tax na przykładach w wybranych państwach, wskazanie jego słabych i mocnych stron oraz możliwych wyzwań implementacji. 
sin tax, health tax/taxation, hypothecation/earmarking, the databases of scientific publications PubMed and Cochrane were searched. These databases are most commonly used for literature reviews according to the guidelines for Agency for Health Technology Assessment and Tariff System reviews. In addition, World Health Organization documents were analysed and legislative solutions in Europe and worldwide were reviewed according to availability in selected countries. The results show the mechanism of sin tax tool operation, the main advantages and disadvantages of this type of tax, and finally, the examples of $\sin$ tax functioning in selected countries are presented.

\section{RESULTS}

Sin tax is a tax, according to the World Health Organisation, levied on products that are harmful to health in order to reduce their consumption. The most well-known and widely used public health tax to reduce the consumption of harmful products is the tax on tobacco and alcohol (4).

The functioning of sin tax is based on the principle of earmarking. This principle is based on a close link between revenue and expenditure, i.e. that the tax revenue resulting from the application of sin tax on products harmful to health should be allocated in whole or in part to health care activities, in particular to health care programmes for the prevention of diseases caused by the consumption of the product (5). The most important arguments for the application of the earmarking principle include securing funds in the budget for specific measures, greater efficiency of public expenditure, raising public awareness of the costs incurred for specific benefits. The main drawbacks of this economic solution are the weakening of the principle of solidarity of public finance, the possibility of misallocating funds or using them for lobbying activities (6). Earmarking is not a specific tool for the system of financing health care and the above arguments refer to every sector in which it will be applied.

The main feature distinguishing sin tax from other indirect taxes imposed on selected groups of products is its preventive effect. A characteristic feature of a public health tax is the assumption that there is a decline in self-control and overconsumption of harmful products in society (7). The overriding role of $\sin$ tax, as in the case of other taxes, is not to ensure revenue for the state budget, but to prevent the consumption of harmful products by increasing their price. There are two basic mechanisms of tax levying. In an ad valorem approach, the amount of tax is charged on the value of the finished product. In the second approach, $\sin$ tax takes the form of a precise tax which targets

\section{MATERIAŁ I METODY}

W pierwszej kolejności przeprowadzono przegląd piśmiennictwa naukowego. Na podstawie kwerend wyszukiwania w oparciu o słowa kluczowe: sin tax, health tax/taxation, hypothecation/earmarking przeszukano bazy publikacji naukowych PubMed i Cochrane. Bazy te są najczęściej używane do przeglądów piśmiennictwa zgodnie $\mathrm{z}$ wytycznymi dla przeprowadzania przeglądów AOTMiT. Dodatkowo przeanalizowano dokumenty Światowej Organizacji Zdrowia oraz dokonano przeglądu rozwiązań legislacyjnych obowiązujących w Europie i na świecie według dostępności w wybranych krajach. $\mathrm{W}$ wynikach przedstawiono mechanizm działania narzędzia sin tax, wskazano główne zalety i wady tego rodzaju podatku, na końcu przedstawiono przykłady funkcjonowania $\sin$ tax w wybranych krajach.

\section{WYNIKI}

Sin tax to podatek, według Światowej Organizacji Zdrowia nakładany na produkty, które niekorzystnie wpływają na zdrowie w celu ograniczenia ich spożycia. Najbardziej znanym i powszechnie stosowanym podatkiem zdrowia publicznego, który ma za zadanie ograniczyć konsumpcję produktów szkodliwych jest podatek nakładany na wyroby tytoniowe i alkohol (4).

Funkcjonowanie sin tax działa na zasadzie earmarkingu. Zasada ta opiera się na ścisłym powiązaniu między przychodami a wydatkami, znaczy to, iż wpływy podatkowe wynikające $z$ obowiązywania sin tax na produkty szkodliwe dla zdrowia powinny być w całości lub w znacznej części, przeznaczane na działania z zakresu ochrony zdrowia, szczególnie na programy profilaktyki schorzeń spowodowanych konsumpcją danego produktu (5). Do najważniejszych argumentów na rzecz stosowania zasady earmarkingu zaliczyć należy zabezpieczenie środków w budżecie na konkretne działania, większą efektywność wydatków publicznych, podwyższanie świadomości społeczeństwa na temat kosztów ponoszonych na dane świadczenia. Jako główne wady tego rozwiązania ekonomicznego przedstawia się osłabienie zasady solidarności finansów publicznych, możliwość błędnej alokacji środków pieniężnych, czy wykorzystanie ich do działań lobbystycznych (6). Earmarking nie jest narzędziem swoistym dla systemu finansowania ochrony zdrowia i powyższe argumenty odnoszą się do każdego sektora, w którym zostanie zastosowany.

Główną cechą odróżniającą sin tax od innych podatków pośrednich nałożonych na wybrane grupy produktów jest jego działanie profilaktyczne. Charakterystyczne dla podatku zdrowia publicznego jest założenie, że w społeczeństwie dochodzi do spadku samokontroli oraz nadkonsumpcji produktów szkodliwych (7). Nadrzędną rolą sin tax nie jest, jak w przypadku innych podatków, 
a specific component (a fixed charge per $1 \mathrm{~g}$ of sugar in sweetened beverages in the United Kingdom) (8). The adoption of the second tax mechanism results in all products being subject to the same tax. When paid ad valorem, premium products are taxed more heavily, which translates into greater price differentiation and leaves consumers free to choose cheaper alternatives and the effect of behavioural modification is weaker (9).

The introduction of any kind of mandatory levies is linked to the reaction of stakeholder groups. In the case of $\sin$ tax, there is a tripartite model of groups affected by the tax. The first group is the government, which is interested in two results of the tax: changing the behaviour of the society and increasing revenues to public funds. Decision-makers are in favour of the tax (2). The second group is made up of manufacturers. Producers of taxed goods are in principle negative towards tax. The third group of stakeholders is society. In the subject of sin tax, it is dealt with in a dualistic manner. On the one hand, citizens are consumers of goods, who are burdened with additional costs and thus may adopt a negative attitude. On the other hand, society is treated as a beneficiary of an increased pool of funds for health care, which translates into favourable tax treatment (2).

Taxes on unhealthy products such as alcohol, tobacco and sweetened drinks are widely used in 31 countries around the world. Governments may use fiscal policies or regulations to influence the prices of products with potential adverse health effects to change their level of consumption (10). For example, the sharp rise in alcohol taxes in Sweden has been followed by a significant fall in consumption and the incidence of underage drinking fraud (11). Similarly, in the United States, tobacco taxes have significantly reduced smoking rates and generated revenue to reduce harmful health effects of tobacco consumption (11). On the other hand, policies aimed at raising commodity prices, such as taxes, raise public concerns as they may impose an unfair financial burden on lowincome households (12).

Non-communicable diseases are a major cause of premature death in most countries around the world (13). Scientific evidence suggests that demand for goods that may affect health responds to price changes (13). This justifies the expectation that an appropriate pricing policy will have beneficial health effects. The effectiveness of applying sin tax to changes in consumer behaviour can be measured in three ways: through experimentation, controlled research on price changes and modelling. So far, few studies have focused on the direct impact of taxes on dietary behavioural changes. Several studies of this type have been carried out in the United States, but none of them have shown zapewnienie wpływów do budżetu państwa, a działanie zapobiegawcze, polegające na ograniczeniu spożycia szkodliwych produktów poprzez podniesienie ich ceny. Rozróżnia się dwa podstawowe mechanizmy nakładania podatku. W podejściu ad valorem kwota podatku naliczana jest od wartości gotowego produktu. W drugim podejściu sin tax przyjmuje formę podatku precyzyjnego, który celowany jest w konkretny składnik (stała opłata za $1 \mathrm{~g}$ cukru w napojach słodzonych w Wielkiej Brytanii) (8). Przyjęcie drugiego mechanizmu podatkowania powoduje objęcie wszystkich produktów takim samym podatkiem. Przy opłacie ad valorem produkty premium są wyżej opodatkowane, co przekłada się na większe zróżnicowanie cen i pozostawia konsumentom możliwość wyboru tańszych odpowiedników, a efekt modyfikacji zachowań jest słabszy (9).

Wprowadzenie każdego rodzaju obowiązkowej daniny wiąże się z reakcją grup interesariuszy. W przypadku sin tax funkcjonuje model trójstronny grup, na które oddziałuje podatek. Pierwszą grupą jest rząd, który jest zainteresowany dwoma rezultatami podatku: zmianą zachowań społeczeństwa i zwiększeniem wpływów do środków publicznych. Decydenci przyjmują postawę przychylną podatkowi (2). Drugą grupę stanowią wytwórcy. Producenci obłożonego podatkiem dobra są z zasady negatywnie nastawieni do podatku. Trzecią grupą interesariuszy jest społeczeństwo. $W$ temacie sin tax rozpatrywane jest ono w sposób dualistyczny. Z jednej strony obywatele są konsumentami dóbr, którzy zostają obciążeni dodatkowymi kosztami i przez to mogą przyjąć postawę negatywną. Z drugiej strony społeczeństwo traktowane jest jako beneficjent zwiększonej puli środków na ochronę zdrowia, co przekłada się na sprzyjanie podatkowi (2).

Podatki od niezdrowych produktów, takich jak alkohol, tytoń czy słodzone napoje są powszechnie stosowane w 31 krajach na świecie. Rządy mogą wykorzystywać politykę fiskalną lub regulacje prawne, aby wpływać na ceny produktów o potencjalnym niekorzystnym wpływie na zdrowie, w celu zmiany poziomu ich konsumpcji (10). Na przykład po gwałtownym wzroście podatków na alkohol w Szwecji nastąpił znaczny spadek konsumpcji oraz występowania nadużyć związanych ze spożywaniem alkoholu przez osoby nieletnie (11). Podobnie w Stanach Zjednoczonych podatki od wyrobów tytoniowych spowodowały znaczny spadek odsetka osób palących, a także wygenerowały przychody, które służą do ograniczenia szkodliwych skutków zdrowotnych palenia tytoniu (11). Z drugiej strony działania polityczne mające na celu podniesienie cen towarów, takie jak podatki, wywołują obawy społeczne, ponieważ mogą nakładać niesprawiedliwe obciążenia finansowe na gospodarstwa domowe o niskich dochodach (12).

Choroby niezakaźne stanowią główną przyczynę przedwczesnych zgonów w większości krajów na świe- 
a significant correlation between the introduction of taxes and the reduction of obesity rates. The authors conclude that this may be related to the level of taxes (between $1 \%$ and $8 \%$ ), which was insufficient to notice population changes (14).

Controlled price change surveys are considered to be one of the better measures for measuring effectiveness. They consist of price manipulation in a closed or simulated environment. Studies of this type have shown that the introduction of taxes on unhealthy food can reduce food consumption (15). Modelling, on the other hand, uses economic indicators such as price elasticity to estimate how price changes will affect dietary behaviour in the population. Modelling has estimated that a $20 \%$ tax on sweetened beverages could reduce the percentage of obese people in the United States by 3.5\% (16).

The first sin tax of $5 \%$ of the value of the product was introduced to tobacco products in Victoria, Australia, in 1987, and the tax funds were used to set up a health promotion foundation (5). Since then, more and more countries around the world have started to introduce sin tax solutions. According to WHO data, in 2014, 35 countries allocated all or part of their tobacco tax revenues to health. In 9 countries, the revenues from alcohol taxation were allocated to health care. Some countries (e.g. Great Britain, France, Hungary and the Philippines), due to the obesity and diabetes epidemic, imposed an additional tax on food products containing large amounts of sugar, mainly sugar sweetened beverages (SSB) (17).

In 2010, Denmark introduced a tax on saturated fats paid when the weight of fats present in a food and used to prepare it exceeded $2,3 \mathrm{~g} / 100 \mathrm{~g}$. The tax was $\mathrm{DKr}$ 16.00 (EUR 2.15) per kilogram of saturated fat. The tax was abolished in 2013 as a result of protests from the food industry and poor government coordination. It was not evaluated (18). Another European example of the introduction of sin tax is France, where a tax on sugar-sweetened or sweetened beverages has been in place since 2011. The current rate is $7.5 \mathrm{EUR} / \mathrm{hl}$, imposed on food producers, importers and premises serving prepared sweetened beverages. All income from the tax is used for social insurance in case of illness. The tax has not met with resistance from the public and the food sector (18). In Finland, sweets and ice cream are also included in the tax on sweetened drinks. The tax rate is EUR 0,95 per kilogram of sweets and ice cream. In the case of non-alcoholic beverages, the amount of taxation is EUR 0,11 per litre. Beverages containing more than $0.5 \%$ sugar are subject to a higher tax - EUR 0.22 per litre. No official evaluation results are available, but consumption of sweetened drinks and sweets has fallen (18). Compared to the economic solutions in these countries cie (13). Dowody naukowe wskazują, że popyt na towary mogące negatywnie wpływać na zdrowie reaguje na zmiany ceny (13). Uzasadnia to oczekiwanie, iż odpowiednia polityka cenowa przyniesie korzystne skutki zdrowotne. Efektywność stosowania sin tax w odniesieniu do zmian zachowań konsumentów można zmierzyć na trzy sposoby: poprzez eksperyment, kontrolowane badania zmian ceny oraz modelowanie. Dotychczas niewiele badań dotyczyło bezpośredniego wpływu podatków na zmiany zachowań żywieniowych. W Stanach Zjednoczonych przeprowadzono kilka badań tego typu, jednak żadne z nich nie udowodniło istotnej korelacji między wprowadzeniem podatków a zmniejszeniem odsetka osób otyłych. Autorzy badań wnioskują, iż związane może to być z wysokością podatków (między 1\% a 8\%), która była niewystarczająca, by zauważyć zmiany populacyjne (14).

Kontrolowane badania zmian ceny uważane są za jeden z lepszych mierników badania efektywności. Polegają one na manipulowaniu ceną w zamkniętym bądź symulowanym środowisku. W badaniach tego typu udowodniono, iż wprowadzenie podatków od niezdrowej żywności może wpływać na ograniczenie jej konsumpcji (15). Z kolei w modelowaniu używa się wskaźników ekonomicznych, takich jak elastyczność cenowa, w celu oszacowania, jak zmiana ceny wpłynie na zachowania żywieniowe w populacji. Przy pomocy modelowania oszacowano, iż $20 \%$ podatek od słodzonych napojów może doprowadzić do redukcji odsetka osób otyłych w Stanach Zjednoczonych o 3,5\% (16).

Pierwszy sin tax w wysokości 5\% wartości produktu został wprowadzony w australijskim stanie Victoria w 1987 roku na wyroby tytoniowe, a fundusze pochodzące z podatku zostały przeznaczone na powstanie fundacji zajmującej się promocją zdrowia (5). Od tego czasu coraz więcej państw na świecie zaczęło wprowadzać rozwiązania sin tax. Według danych WHO w 2014 roku 35 państw przeznaczało całość lub część wpływów z podatku od wyrobów tytoniowych na zdrowie. W 9 krajach wpływy z opodatkowania alkoholu przeznaczane były na opiekę zdrowotną. Część państw (m.in. Wielka Brytania, Francja, Węgry czy Filipiny), w związku z epidemią otyłości i cukrzycy obłożyła dodatkowym podatkiem produkty żywieniowe zawierające duże ilości cukru, przede wszystkim napoje słodzone (SSB, ang. sugar sweetened beverages) (17).

W 2010 roku Dania wprowadziła podatek od thuszczów nasyconych płacony, gdy gramatura tłuszczów obecnych w żywności i wykorzystanych do jej przygotowania przekraczała $2,3 \mathrm{~g} / 100 \mathrm{~g}$. Podatek wynosił $16,00 \mathrm{DKr}(2,15$ EUR) za kilogram thuszczu nasyconego. Podatek został zniesiony w 2013 na skutek protestów ze strony branży producentów żywności oraz słabej koordynacji ze strony rządu. Nie została przeprowadzona jego ewaluacja (18). Kolejnym europejskim przykładem wprowadzenia sin tax jest Fran- 
targeting one ingredient (sugar), a broad public health tax was introduced in Hungary. According to the law, all groups of food products that can be classified as unhealthy food are subject to taxation. First of all, it is a highly processed food, rich in sugar, fat, salt and methylxanthin. Products with a healthier equivalent are subject to the tax. The rates are differentiated within one product group, such as concentrates and syrups (concentrate content $>25 \%$ ) are taxed at $€ 0.64$ per litre; sweetened drinks with sugar content $>8 \mathrm{~g} / 1$ are taxed at $€ 0.02$ per litre. The food industry has been encouraged to reform its products. As a result, 30\% of the evaluated food producers completely removed the unfavourable ingredients and $70 \%$ reduced their amount. The revenues from the tax are fully allocated to health care. The official evaluation of the tax confirmed the decrease in consumption by $20-35 \%$. Among the respondents, $80 \%$ indicated price as the reason for reduced consumption of products (19).

\section{CONCLUSIONS}

A definite advantage of the $\sin$ tax tool is its effectiveness in changing the consumption habits of the population. Many studies confirm that such actions contribute to the improvement of the health status of the population, especially in aspects of nutritional behaviours (20). It should be borne in mind that the effectiveness of sin tax on the health of the population depends on the amount of tax imposed on a given good (e.g. cigarettes or sweets) (20). A Mexican survey based on statistical modelling published in 2016 confirms that the introduction of a tax on sweetened beverages can make a significant contribution to improving the health of the population and thus reducing health care costs $(21,22)$. A further study presents the impact of a tax called "penny-for-ounce" on reducing consumption of sweetened beverages in California. Within a decade after the introduction of the $20 \%$ tax, a decrease in sweetened beverage consumption should lead to a 3.4\% decrease in the incidence of diabetes and a $1 \%$ decrease in the incidence of ischemic heart disease, while the savings associated with treating diabetes are estimated at up to $\$ 620$ million (23).

One of the most common arguments against taxation of tobacco, alcohol or sweetened beverages is the fact that such taxes are regressive. Studies have shown that price increases are most likely to affect the income of those with low socioeconomic status. It seems that this intervention is socially unjust, because in this way people with lower incomes are forced to bear relatively higher costs related to the introduction of new taxes on some goods than people with higher incomes. On the other hand, health effects of this intervention are progressive in nature, therefore health inequalities may cja, gdzie od 2011 r. obowiązuje podatek od napojów słodzonych cukrem lub słodzikiem. Obecna stawka wynosi 7,5 EUR/hl, nakładana jest na producentów żywności, importerów oraz lokale podające przez siebie przygotowane napoje słodzone. Całość wpływów $\mathrm{z}$ podatku jest przeznaczana na ubezpieczenia społeczne na wypadek choroby. Podatek nie spotkał się z oporem społeczeństwa i sektora spożywczego (18). W Finlandii podatkiem od napojów słodzonych objęto też słodycze i lody. Stawka podatku wynosi 0,95 EUR na kilogram słodyczy i lodów. W przypadku niealkoholowych napojów kwota opodatkowania wynosi 0,11 EUR za litr. Napoje zawierające ponad $0,5 \%$ cukru obciążone są wyższym podatkiem - 0,22 EUR za litr. Brak jest wyników oficjalnej ewaluacji, ale odnotowano spadek konsumpcji napojów słodzonych i słodyczy (18). W porównaniu z rozwiązaniami ekonomicznymi w wymienionych krajach nakierowanymi na jeden składnik (cukier), na Węgrzech wprowadzono szeroki podatek zdrowia publicznego. Według prawa opodatkowaniu podlegają wszystkie grupy produktów spożywczych, które można zakwalifikować do kategorii niezdrowej żywności. Przede wszystkim jest to żywność wysoko przetworzona, bogata w cukier, thuszcz, sól i metyloksantyny. Podatkiem objęte zostały produkty posiadające zdrowszy odpowiednik. Stawki są zróżnicowane w obrębie jednej grupy produktów, jak koncentraty i syropy (zawartość koncentratu $>25 \%$ ) obłożone są kwotą 0,64 EUR za litr; napoje słodzone z zawartością cukru $>8 \mathrm{~g} / 1$ opodatkowane są stawką 0,02 EUR/1. Branża spożywcza została zachęcana do reformulacji swoich produktów. W efekcie $30 \%$ producentów żywności objętych ewaluacją całkowicie usunęło niekorzystne składniki, a 70\% zmniejszyło ich ilość. Wpływy z podatku są w całości przeznaczane na ochronę zdrowia. Oficjalna ewaluacja podatku potwierdziła spadek konsumpcji o 20-35\%. Wśród przebadanych osób $80 \%$ podało cenę jako powód zmniejszonego spożycia produktów (19).

\section{WNIOSKI}

Zdecydowaną zaletą narzędzia sin tax jest jego skuteczność w zmianach nawyków konsumpcyjnych populacji. Wiele badań potwierdza, iż takie działania przyczyniają się do poprawy stanu zdrowia populacji, zwłaszcza w aspektach zachowań żywieniowych (20). Należy przy tym pamiętać, że skuteczność odziaływania sin tax na stan zdrowia populacji zależy od wysokości podatku nałożonego na dane dobro (np.: papierosy czy słodycze) (20). Opublikowane w roku 2016 badanie z Meksyku oparte o modelowanie statystyczne potwierdza, że wprowadzenie podatku od słodzonych napojów może w istotny sposób przyczynić się do poprawy stanu zdrowia ludności oraz tym samym 
decrease (24). In this case, it is necessary to take into account all effects of a given measure, including related health benefits, externalities and health care costs.

Another challenge when considering the effectiveness of $\sin$ tax is the desirability of collecting additional revenue from the state budget. The effectiveness of intervention in perpetuating pro-health behaviour in the form of sin tax on goods commonly considered as "unhealthy" is possible to obtain if the funds are used, for example, for preventive actions. It happens that despite increased state revenues from taxes on unhealthy goods, these funds are not allocated for the protection of citizens' health. Then we cannot speak of a beneficial impact of $\sin$ tax on the health of the population or prevention of civilisation diseases (25).

When sin tax is introduced, there is also a conflict between state interventionism and individual autonomy. Stakeholders in the free market often characterise taxes, including sin tax, as government intervention in the free market system. One of the biggest barriers to applying the sin tax tool is the resistance of the environment of producers whose products are to be subject to taxation. This can be seen in particular in the case of the non-alcoholic beverages industry. Du M. et al. in Sugar-Sweetened Beverage Taxes: Industry Response and Tactics discusses the strategy adopted by producers, which is based on, among other things, undermining the negative impact of a given nutritional product on health or aggressive marketing (27). Influencing consumer perception strengthens social resistance to the new tax. Therefore, at the stage of conceptual work on the new tax, it is important to create a professional literature review consisting of studies conducted in objective conditions and to undertake information activities aimed at the society at the level of preliminary legislative works. The involvement of local organisations, philanthropists or celebrities played a key role in the adoption of many existing taxes on food products, e.g. in Great Britain, Mexico or in some cities of the United States (28).

\section{SUMMARY}

The sin tax solution has a number of arguments for and against its application. Opponents of sin tax perceive it as a paternalistic solution, i.e. one that restricts the freedom of consumption of society and the free market. In addition, it is regressive in nature and places the greatest burden on people with low economic status. On the other hand, it is indicated as an effective tool for shaping the health behaviour of society. Whether sin tax will have the intended positive effect depends, however, above all, on its proper construction. It should be remembered that sin tax is effective when it forms part of a broad prevention campaign, as was the case zmniejszyć koszty opieki zdrowotnej $(21,22)$. W kolejnym badaniu przedstawiono wpływ podatku, który nazwano ,penny-for-ounce" na zmniejszenie konsumpcji napojów słodzonych w Kalifornii. W ciągu dekady po wprowadzeniu dodatkowego podatku $20 \%$ spadek konsumpcji słodzonych napojów powinien doprowadzić do 3,4\% spadku zapadalności na cukrzycę i $1 \%$ spadku zapadalności na chorobę niedokrwienną serca, zaś oszczędności związane z leczeniem cukrzycy szacuje się nawet na $620 \mathrm{mln}$ dolarów (23).

Jednym z najczęstszych argumentów przeciw opodatkowaniu tytoniu, alkoholu lub napojów słodzonych jest fakt, że takie podatki mają charakter regresywny. W badaniach wykazano, iż wydatki związane ze wzrostem cen w największym stopniu wpływają na dochody osób o niskim statusie społeczno-ekonomicznym. Wydaje się, że jest to interwencja niesprawiedliwa społecznie, bowiem w ten sposób osoby o niższych dochodach zmuszane są do ponoszenia relatywnie większych kosztów związanych z wprowadzeniem nowych podatków od niektórych dóbr niż osoby o wyższych dochodach. Z drugiej strony efekty zdrowotne tej interwencji mają charakter progresywny, w związku z czym nierówności w zdrowiu mogą się zmniejszać (24). Konieczne jest w tym wypadku uwzględnienie wszystkich skutków danego działania, w tym związanych z nimi korzyści zdrowotnych, efektów zewnętrznych oraz kosztów opieki zdrowotnej.

Kolejnym wyzwaniem przy rozważaniu skuteczności sin tax jest celowość gromadzenia dodatkowych dochodów w budżecie państwa. Skuteczność interwencji w utrwalaniu prozdrowotnych zachowań w postaci sin tax na towary powszechnie uważane za „niezdrowe” jest możliwa do uzyskania wtedy, gdy środki z tego tytułu zostaną wykorzystane np.: na działania profilaktyczne. Zdarza się bowiem, iż mimo zwiększonych dochodów państwa z tytułu podatków od niezdrowych towarów, środki te nie są przeznaczane na ochronę zdrowia obywateli. Wówczas nie można mówić o korzystnym wpływie sin tax na zdrowie populacji, czy zapobieganie chorobom cywilizacyjnym (25).

Przy wprowadzaniu sin tax pojawia się również konflikt między interwencjonizmem państwowym a autonomią jednostki. Interesariusze wolnego rynku często charakteryzują podatki, w tym podatki sin tax, jako ingerencję rządu w wolny system rynkowy. Jedną z największych barier przy aplikacji narzędzia sin tax jest opór środowiska producentów, których produkty mają zostać objęte opodatkowaniem. Widać to w szczególności na przykładzie branży napojów bezalkoholowych. $D u M$. et al. w publikacji Sugar-Sweetened Beverage Taxes: Industry Response and Tactics omawiają strategię przyjmowaną przez producentów, która opiera się m.in. na podważaniu negatywnego wpływu danego produktu żywieniowego na zdrowie czy agresywnym marketingu 
in Australia on tobacco products. In addition, to limit its impact on vulnerable groups, it should be modelled accordingly. Based on the observations and experiences of countries, the following principles should be taken into account in order to construct an effective public health tax: 1) targeting the tax on a particular component results in a better health outcome, 2) taking other health promotion and prevention measures at the same time, 3 ) introducing subsidies or reducing taxes on healthy products. The introduction of a tax on certain groups of products limits their availability to consumers, at the same time lowering the prices of nutritiously valuable products creates an alternative for the society and allows to achieve a better health effect, 4) decisionmakers should prepare a strategy for counteracting the claims of the manufacturing industry and a broad information campaign at the stage of legislative work on the significance of the new tax, 5) the revenues obtained should be fully allocated to health care financing. The results show that $\sin$ tax is a tool which, if properly applied, can bring measurable benefits.

\section{REFERENCES}

1. Caraher M, Carr-Hill R. Taxation and Population Health: "Sin Taxes" or Structured Approaches. W: Sandro G. Macrosocial Determinants of Population Health. New York: Springer; 2007: 211

2. Green R. The Ethics of Sin Taxes. Public Health Nursing Rok.; 28. (1): 68-77

3. World Health Organization. 2008-2013. Action plan for the global strategy for the prevention and control of noncommunicable diseases. Geneva: WHO; 2008

4. World Health Organization. Health financing for universal coverage. https:/www.who.int/health_financing/topics/public-health-taxes/en/ (dostęp: 14.08.2019)

5. Doetinchem O. Hypothecation of tax revenue for health. World Health Report (2010) Background Paper, No 51. Geneva: WHO; 2010: 2-3

6. Cashin C, Sparkes S, Bloom D. Earmarking for health: from theory to practice Health Financing Working Paper No. 5, Geneva: WHO; 2017: 13-14

7. Cremer H, De Donder P, Maldonado D. Taxing Sin Goods and Subsidizing Health Care. Scand J Economics 2012;114(1): 101-123

8. Wright A, Smith KE, Hellowell M. Policy lessons from health taxes: a systematic review of empirical studies. BMC Public Health. 2017 Jun 19;17(1):583

9. Blecher E. Taxes on tobacco, alcohol and sugar sweetened beverages: Linkages and lessons learned. Social Science \& Medicine 136-137 (2015) $175: 179$
(27). Wpływanie na percepcję konsumentów wzmacnia opór społeczny przed nowym podatkiem. W związku $\mathrm{z}$ tym istotne jest na etapie prac koncepcyjnych nad nowym podatkiem stworzenie profesjonalnego przeglądu literatury, składającego się z badań przeprowadzonych w obiektywnych warunkach oraz podjęcie działan informacyjnych skierowanych do społeczeństwa na poziomie wstępnych prac legislacyjnych. Zaangażowanie organizacji lokalnych, filantropów czy celebrytów odegrało kluczową rolę w przyjęciu wielu istniejących podatków na produkty żywnościowe, m.in. w Wielkiej Brytanii, Meksyku czy w części miast Stanów Zjednoczonych (28).

\section{PODSUMOWANIE}

Rozwiązanie typu sin tax posiada szereg argumentów przemawiających za jego stosowaniem, jak i przeciw niemu. Przeciwnicy sin tax postrzegają go jako rozwiązanie paternalistyczne, czyli ograniczające swobodę konsumpcyjną społeczeństwa oraz wolnego rynku. Dodatkowo ma on regresywny charakter, w największy sposób obciąża osoby o niskim statusie ekonomicznym. Z drugiej strony wskazywany jest jako skuteczne narzędzie kształtujące zachowania zdrowotne społeczeństwa. To czy sin tax będzie przynosił zamierzony pozytywny efekt zależy jednak przede wszystkim od jego odpowiedniej konstrukcji. Należy pamiętać, iż sin tax przynosi efekty, gdy stanowi część szerokiej kampanii profilaktycznej, jak to było z przeprowadzone w Australii w temacie wyrobów tytoniowych. Dodatkowo, żeby ograniczyć jego oddziaływanie na grupy o słabszej sytuacji społeczno-ekonomicznej, powinien zostać odpowiednio modelowany. Na podstawie obserwacji i doświadczeń państw, żeby skonstruować efektywny podatek zdrowia publicznego należy uwzględnić następujące zasady: 1) kierunkowanie podatku na konkretny składnik przynosi lepszy wynik zdrowotny, 2) podejmowanie jednocześnie innych działań z zakresu promocji zdrowia i profilaktyki, 3) wprowadzenie dotacji lub obniżenie podatków na produkty zdrowe. Wprowadzenie podatku na pewne grupy produktów powoduje ograniczenie ich dostępności dla konsumentów, jednoczesne obniżenie cen produktów wartościowych odżywczo tworzy alternatywę dla społeczeństwa i pozwala na uzyskanie lepszego efektu zdrowotnego, 4) decydenci powinni przygotować strategię odpierania zarzutów branży wytwórców oraz szeroką kampanię informacyjną na etapie prac legislacyjnych na temat znaczenia nowego podatku, 5) uzyskane wpływy powinny być w całości przekazywane na finansowanie ochrony zdrowia. Wyniki pokazują, że sin tax jest to narzędzie, które odpowiednio zastosowane może przynieść mierzalne korzyści. 
10. Franco Sassi, Annalisa Belloni, Andrew J Mirelman, Marc Suhrcke, Alastair Thomas, Nisreen Salti, Sukumar Vellakkal, Chonlathan Visaruthvong, Barry M Popkin, Rachel Nugent, Equity impacts of price policies to promote healthy behaviours, The Lancet, Vol 391, Issue 10134, 2018, p. 2059-2070

11. Chaufan, C., Hong, G. H., \& Fox, P. "Sin-Food" Taxes and Sugar-Sweetened Beverages-The Right Policy for the Wrong Reasons? American Journal of Health Promotion, 2010, 25(2), 87-9

12. Hacker GA. Taxing booze for health and wealth. J Policy Anal Manage. 1987;6:701-708

13. Perviz Asaria, Dan Chisholm, Colin Mathers, Majid Ezzati, Robert Beaglehole, Chronic disease prevention: health effects and financial costs of strategies to reduce salt intake and control tobacco use, The Lancet, Vol 370, Issue 9604, 2007: 2044-2053

14. Medical Research Council [editorial]. Using natural experiments to evaluate population health interventions: guidance for producers and users of evidence. MRC, 2011

15. Epstein LH, Jankowiak N, Nederkoorn C, Raynor HA, French SA, Finkelstein E. Experimental research on the relation between food price changes and food-purchasing patterns: a targeted review. Am J Clin Nutr 2012;95:789-809

16. Lin BH, Smith TA, Lee JY, Hall KD. Measuring weight outcomes for obesity intervention strategies: the case of a sugar-sweetened beverage tax. Econ Hum Biol 2011;9:329-41

17. Vall Castello J, Lopez Casasnovas G, Impact of SSB taxes on consumption, CRES-UPF Working Paper 201804-110, Barcelona 2018

18. World Health Organization, Fiscal Policies for Diet and Prevention of Noncommunicable Diseases, Technical Meeting Report 5-6 May 2015, Geneva, Switzerland

19. Act on Excise Duty on Sweets, Ice-Cream and Soft Drinks of 17 December 2010 (1127/2010), http:// ec.europa.eu/taxation customs/tedb/legacy/taxDetail.html;jsessionid $=$ uMWaczndm_maOqOYISfxtlFdMVV23aOTRAjnxLh62Vtx_SCLeFfs! $-1431204286 ? \mathrm{id}=2001 / 1424159141 \& \operatorname{tax}$ Type $=$ Oth er\%20indirect\%20tax (dostęp: 28.08.2019)

20. Hagenaars L, Jeurissen P, Klazinga N. The taxation of unhealthy energy-dense foods (EDFs) and sugar-sweetened beverages (SSBs): An overview of patterns observed in the policy content and pol- icy context of 13 case studies. Health Policy 121 (2017) 887-894

21. Sánchez-Romero L, Penko J, Coxson P. et al. Projected Impact of Mexico's Sugar-Sweetened Beverage Tax Policy on Diabetes and Cardiovascular Disease: A Modeling Study. PLOS Med. 13. 10.1371/journal.pmed.1002158

22. Batis C, Rivera JA, Popkin BM, Taillie LS. FirstYear Evaluation of Mexico's Tax on Nonessential Energy-Dense Foods: An Observational Study. PLoS Med. 2016 Jul 5;13(7):e1002057

23. Mekonnen TA, Odden MC, Coxson PG. Health benefits of reducing sugar-sweetened beverage intake in high risk populations of California: results from the cardiovascular disease (CVD) policy model. PLoS One. 2013 Dec 11;8(12):e81723

24. Smed S, Jensen JD, Denver S. Socio-economic characteristics and the effect of taxation as a health policy instrument. Food Policy2007;32:624-39

25. Block JP, Chandra A, McManus KD, Willett WC. Point-of-purchase price and education intervention to reduce consumption of sugary soft drinks. Am J Public Health2010;100:1427-33

26. Roache SA, Gostin LO. Tapping the Power of Soda Taxes: A Call for Multidisciplinary Research and Broad-Based Advocacy Coalitions - A Response to the Recent Commentaries. Int J Health Policy Manag. 2018 Apr 8;7(7):674-676

27. Du M, Tugendhaft A, Erzse A, Hofman KJ. SugarSweetened Beverage Taxes: Industry Response and Tactics. Yale J Biol Med. 2018 Jun 28;91(2):185190

28. Wright A., Smith K.E., Hellowell M. Policy lessons from health taxes: a systematic review of empirical studies. BMC Public Health. 2017;17(583):1-14

Received: 23.09.2019

Accepted for publication: 14.11.2019

Otrzymano: 23.09.2019 r.

Zaakceptowano do publikacji: 14.11.2019 r.

\section{Adres do korespondencji:}

Address for correspondence:

Monika Pajewska

Narodowy Instytut Zdrowia Publicznego - Państwowy

Zakład Higieny

ul. Chocimska 24, 00-770 Warszawa 